\title{
Apparent Nutrient Digestibility Assessment and Influence of Gelatinized and Non-gelatinized Corn Starch Based Diet in Labeo rohita
}

Farkhanda Asad, Mahwish Qamer* and Nimra Tahir

Department of Zoology, Wildlife and Fisheries, GC University Faisalabad, Pakistan

\begin{abstract}
Gelatinized and non-gelatinized corn starch based diet was processed at varying protein levels for apparent nutrient (dry matter, ash, crude fat, crude protein and gross energy) digestibility coefficient (ADC) evaluation in Labeo rohita. For a tryout of 120 days, six semi purified diets were assembled (T1: G, 30\% CP; T2: NG, 30\% CP; T3: G, 35\% CP; T4: NG, 35\% CP; T5: G, 40\% CP and T6: NG, 40\% CP) in which two replicates were followed for each diet. Chromic oxide was added being an indigestible marker. Apparent dry matter, crude fat and gross energy digestibility was best exhibited by T6 $(12.00 \%, 79.60 \%$ and $32.10 \%)$ compared to other test diets while apparent protein digestibility was observed maximum in T2 $(67.70 \%)$ followed by T1 $(65.40 \%)$, T6 $(52.60 \%)$, T5 $(40.00 \%)$, T4 $(32.60 \%)$ and T3 $(20.20 \%)$ respectively depicting non-significant variations. In case of ash, the apparent nutrient digestibility was capital in T4 $(18.60 \%)$ comparing others diets where the values being non-significantly different are T3 $(13.40 \%)$, T1 $(13.30 \%)$, T6 $(12.70 \%)$, T5 $(12.30 \%)$ and T2 $(9.79 \%)$ respectively. The described outcomes revealed that Labeo rohita may be able to utilize the non-gelatinized corn starch based diet more efficiently and being economical it spares the protein based cost effective feed.
\end{abstract}

Keywords: Nutrient digestibility; Gelatinized; Labeo rohita

\section{Introduction}

Pakistan, due to the lack of resources in the production rate is low intensive agriculture. Therefore, introducing the cheap energy source i.e. carbohydrates, the production rate can be improved. Fish fauna is rich in Pakistan, but in warm-water fish, only seven species and in cold water fish only two species are grown on commercial level [1]. Carbohydrates are considered energy cheaper food for the animals, but the ability of fish to digest carbohydrates in the diet has been reported to the difference between different species [2]. This difference can be explained by the different activities of endogenous carbohydrate digestive different fish [3]. However, carps can utilize high level of carbohydrates in the diet. Similarly, carnivorous fish are poorly able to utilize carbohydrates rather than herbivorous and omnivorous fish, but it is well known that the tents were reported to be in better utilization of carbohydrates, because of their omnivorous or herbivorous diet [3]. Rohu, one of three carp (IMC) and an omnivorous fish, has the ability to use carbohydrates to $43 \%$ in the diet without adverse health effects [3]. This study aimed to determine the acceptance of corn as the main source of carbohydrates and make a comparison of important aspects of fish metabolism of L. rohita fed corn feed (G/NG) at three protein levels i.e. $30 \%, 35 \%$ and $40 \%$ in practical and economic systems for commercially available species of carp i.e. Labeo rohita. These new formulations minimize the cost of fish and reduce the waste produced by the fish [4].

The semi-crystalline nature of starch granules, as detected by X-ray diffraction studies, consists mainly of short amylopectin chains which form double helices associated into clusters forming crystalline lamellae. Recent reports showed that the crystallinity decreased with increasing amylose content in corn starches. However the precise role played by the amylose in the structure of starch granule is still unclear. Apart from the influence of amylose content on gelatinization, gelatinization temperatures and/or enthalpy increase with the crystallinity. This holds for waxy starches of different botanical origin as well as for low and high amylose corn starches.

\section{Materials and Methods}

\section{Experimental diets}

The basic feed ingredient i.e. corn was procured and ground to make powder which were added approximately $80 \%$ of water (v/w) and autoclaved at 15 psi for one hour to obtain maximum gelatinization. These gelatinized corn ingredients were spread over a tray and dried in oven at $60^{\circ} \mathrm{C}$. The dried mass was then pulverized through a hammer mill with $0.5 \mathrm{~mm}$ screen. Protein source was gelatin and fat free casein, while lipid source was sunflower oil and cod liver oil and carbohydrate source was corn ( $\mathrm{G}$ or NG). Chromic oxide was added as an indigestible marker. All these ingredients (Table 1) were ground and sieved to incorporate into diets and mixed well for 30 minutes, then fish oil was slowly added, while mixing thoroughly. Then the dough was given steam for $5 \mathrm{~min}$ in an autoclave. Vitamin-mineral premix was added after cooling the dough and then pellets of $2 \mathrm{~mm}$ were made by hand pelletizer. The pellets were dried in a drying oven for 48 hours and stored until use. Three different crude protein levels (30\%, 35\% and $40 \%)$ were used to formulate six semi purified diets ( $\mathrm{T}_{1}: \mathrm{G}, 30 \% \mathrm{CP} ; \mathrm{T}_{2}$ : NG, 30\% CP; $\mathrm{T}_{3}: \mathrm{G}, 35 \% \mathrm{CP} ; \mathrm{T}_{4}: \mathrm{NG}, 35 \% \mathrm{CP} ; \mathrm{T}_{5}: \mathrm{G}, 40 \% \mathrm{CP}$ and $\mathrm{T}_{6}$ : $\mathrm{NG}, 40 \% \mathrm{CP}$ ) with either gelatinized or non-gelatinized corn starch.

\section{Experimental design and feeding protocol}

Labeo rohita fingerlings purchased from government fish seed hatchery, Satiana road, Faisalabad were allowed to acclimate at

*Corresponding author: Mahwish Qamer, Department of Zoology, Wildlife and Fisheries, GC University Faisalabad, Pakistan, Tel: 92-033-8618057; E-mail: mahwishqamer@gmail.com

Received April 11, 2014; Accepted July 23, 2014; Published August 02, 2014

Citation: Asad F, Qamer M, Tahir N (2014) Apparent Nutrient Digestibility Assessment and Influence of Gelatinized and Non-gelatinized Corn Starch Based Diet in Labeo rohita. J Aquac Res Development 5: 250 doi:10.4172/21559546.1000250

Copyright: (c) 2014 Asad F, et al. This is an open-access article distributed under the terms of the Creative Commons Attribution License, which permits unrestricted use, distribution, and reproduction in any medium, provided the original author and source are credited. 


\begin{tabular}{|l|c|c|c|}
\hline Ingredient & $\mathbf{3 0} \% \mathbf{C P}$ & $\mathbf{3 5 \%} \mathbf{C P}$ & $\mathbf{4 0} \% \mathbf{C P}$ \\
\hline Casein \% & 26.57 & 30.57 & 35.20 \\
\hline Gelatin \% & 4.00 & 8.00 & 5.00 \\
\hline Corn \% G/NG & 42.43 & 42.43 & 42.4 \\
\hline Cellulose \% & 15.00 & 7.00 & 7.40 \\
\hline Sunflower:Codliver oil (2:1)\% & 8.00 & 8.00 & 6.00 \\
\hline Carboxymethyl cellulose \% & 1.00 & 1.00 & 1.00 \\
\hline Vitamin+mineral mix \% & 2.60 & 2.60 & 2.60 \\
\hline Vitamin C \% & 0.10 & 0.10 & 0.10 \\
\hline Vitamin B \% & 0.10 & 0.10 & 0.10 \\
\hline Glycine \% & 0.20 & 0.20 & 0.20 \\
\hline BHT \% & 0.02 & 0.02 & 0.02 \\
\hline
\end{tabular}

( ${ }^{*}$ the antioxidant ButylatedHydroxy Toluene was added at $0.02 \%$ of the added oil)

Table 1: Percentage composition of test diets.

\begin{tabular}{|l|l|c|c|c|c|c|}
\hline \multicolumn{2}{|l|}{ Treatment } & $\begin{array}{c}\text { Dry matter } \\
\text { (\%) }\end{array}$ & $\begin{array}{c}\text { Ash } \\
\text { (\%) }\end{array}$ & $\begin{array}{c}\text { Crude } \\
\text { fat (\%) }\end{array}$ & $\begin{array}{c}\text { Crude } \\
\text { protein (\%) }\end{array}$ & $\begin{array}{c}\text { Gross } \\
\text { energy (\%) }\end{array}$ \\
\hline $\mathrm{T}_{1}$ & $\mathrm{G}, 30 \% \mathrm{CP}$ & 10.00 & 13.30 & 65.50 & 65.40 & 22.72 \\
\hline $\mathrm{T}_{2}$ & $\mathrm{NG}, 30 \% \mathrm{CP}$ & 9.40 & 9.79 & 68.90 & 67.70 & 22.59 \\
\hline $\mathrm{T}_{3}$ & $\mathrm{G}, 35 \% \mathrm{CP}$ & 7.50 & 13.40 & 72.50 & 20.20 & 26.85 \\
\hline $\mathrm{T}_{4}$ & $\mathrm{NG}, 35 \% \mathrm{CP}$ & 7.50 & 18.60 & 71.80 & 32.60 & 26.00 \\
\hline $\mathrm{T}_{5}$ & $\mathrm{G}, 40 \% \mathrm{CP}$ & 6.90 & 12.30 & 74.70 & 40.00 & 27.70 \\
\hline $\mathrm{T}_{6}$ & $\mathrm{NG}, 40 \% \mathrm{CP}$ & 12.00 & 12.70 & 79.60 & 52.60 & 32.10 \\
\hline
\end{tabular}

The apparent nutrient digestibility coefficient (ADC) of dry matter was maximum for the $\mathrm{T}$ : NG, 40\% CP $(12.00 \%)$ and this was followed by the $\mathrm{T}$ : $\mathrm{G}, 30 \% \mathrm{CP}$ $(10.00 \%), T_{2}: N G, 30 \%$ CP $(9.40 \%), T_{3}: G, 35 \%$ CP, $T_{4}: N G, 35 \%$ CP $(7.50 \%)$ and $\mathrm{T}_{5}: \mathrm{G}, 40 \%$ CP $(6.90 \%)$ respectively.

Table 2: Apparent nutrient digestibility coefficient (\%) of dry matter, ash, crude fat, crude protein and gross energy for test diets using chromic oxide as inert marker.

ambient conditions fed on control diet (NG, 30\% CP) for one week before initiating the trial. After acclimatization, fingerlings were transferred randomly into glass aquaria $[90 \mathrm{~L} \times 30 \mathrm{~W} \times 45 \mathrm{H}(\mathrm{cm})$ with 29 $\mathrm{L}$ water capacities each]. For each treatment there were two replicates and in each replica forty fingerlings were stocked. Fish were given test diets at the rate of $4 \%$ live wet body weight twice a day (morning and afternoon) in the feeding aquarium [5].

\section{Analytical methods}

Representative samples of six experimental diets and dried samples of feces of every replica were homogenized separately in a mortar pestle and chemically analyzed by AOAC protocols [6]: oven drying at $105^{\circ} \mathrm{C}$ for dry matter (DM); microkjeldahl analysis for crude protein, chloroform methanol extraction method [7] for crude fat through 10454 soxtec system HTz, electric furnace for ash. Chromic oxide $\left(\mathrm{Cr}_{2} \mathrm{O}_{3}\right)$ was estimated in dried feed and feces according to Divakaran [8] through UV/VIS2001 spectrophotometer.

\section{Results}

The digestibility of nutrients is not defined precisely in many commercial feeds and it is shown that feed performance and digestibility can be increased with the use of extrusion technology [9]. Present study is comparing the digestibility of gelatinized and non-gelatinized corn feed at various protein levels. Apparent nutrient digestibility coefficient (\%) of test diets is shown in Table 2.

\section{\% Degree of Gelatinization (\%DG)}

The $\%$ degree of gelatinization in the temperature range of $50-95^{\circ} \mathrm{C}$ was followed by the spectrophotometric method based on the formation of amylose-iodine complex. In fact, \%DG based on measurement of absorption peak at $600 \mathrm{~nm}$ can be taken as the ratio of solubilized amylose sites to the total amylose sites available in raw starch. Taking this point into account, a comparison was made between the curves in Figure 1 . The \% degree of solubilized amylose sites to the total in the raw starch was higher for corn starch, followed by Amioca. Although this ratio for Hylon VII was low at lower temperatures, it increased after $80^{\circ} \mathrm{C}$. This corresponded to the point where the increase in $\% \mathrm{~S}$ of Hylon VII started on the solubility curve (Figure 2).

The apparent nutrient digestibility coefficient (ADC) of crude protein was maximum for the $\mathrm{T}_{2}$ : NG, $30 \% \mathrm{CP}(67.70 \%)$ and this was followed by the $\mathrm{T}_{1}$ : G, $30 \% \mathrm{CP}(65.40 \%), \mathrm{T}_{6}: \mathrm{NG}, 40 \% \mathrm{CP}(52.60 \%), \mathrm{T}_{5}$ : G, $40 \% \mathrm{CP}, \mathrm{T}_{4}: \mathrm{NG}, 35 \% \mathrm{CP}(40.00 \%$ and $32.60 \%)$ and $\mathrm{T}_{3}: \mathrm{G}, 35 \% \mathrm{CP}$ (20.20\%) (Table 3-7).

\section{Discussion}

Digestibility describes the fraction of the nutrients of energy in the feedstuff that is not excreted in the feces. Digestibility is one of the most important aspects of evaluating the efficiency of feed stuffs. Yengkokpam [2] reported that increased gelatinization decreased the dry matter digestibility. Similar trend was observed in the present study as non-gelatinized $\mathrm{T}_{6}$ : $\mathrm{NG}, 40 \% \mathrm{CP}$ showed the maximum digestibility.

\section{T1 (G, 30\% CP)}

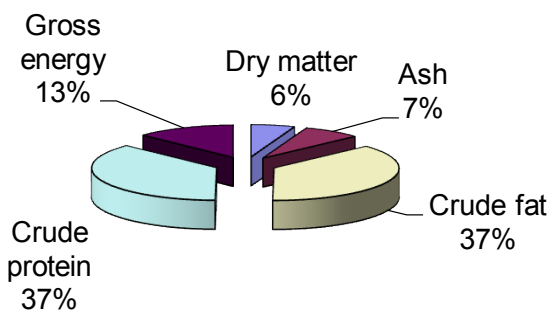

Figure 1: Apparent nutrient digestibility coefficient (\%) for $T_{1}(G, 30 \% \mathrm{CP})$.

T2 (NG, 30\% CP)

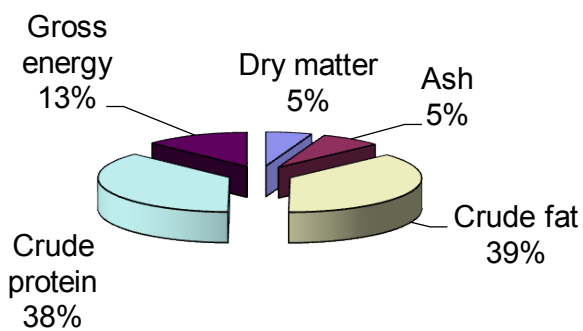

Figure 2: Apparent nutrient digestibility coefficient (\%) for $\mathrm{T}_{2}$ (NG, 30\% CP).

\begin{tabular}{|l|c|c|c|c|}
\hline S.O.V & d.f. & S.S. & MSS & F. Ratio \\
\hline Between diets & 5 & 18.98833 & 3.797667 & $65535^{\mathrm{NS}}$ \\
\hline Within diets & 0 & 0 & 65535 & \\
\hline Total & 5 & 18.98833 & & \\
\hline
\end{tabular}

NS=Non-significant $(P>0.05) ;{ }^{*}=$ Significant $(P<0.05) ;{ }^{* *}=$ Highly significant $(P<0.01)$ The apparent nutrient digestibility coefficient (ADC) of ash was maximum for the $\mathrm{T}_{4}$ : NG, 35\% CP $(18.60 \%)$ and this was followed by the $\mathrm{T}_{3}$ : NG, $35 \% \mathrm{CP}(13.40 \%)$, $\mathrm{T}_{1}$ : G, $30 \%$ CP (13.30\%), T: NG, $40 \%$ CP, $\mathrm{T}_{5}$ : G, $40 \%$ CP $(12.70 \%$ and $12.30 \%)$ and $\mathrm{T}_{2}: \mathrm{NG}, 30 \% \mathrm{CP}(9.79 \%)$ respectively. The results indicate that maximum ash consumption occurs in non-gelatinized corn at $35 \%$ protein level in fish.

Table 3: Analysis of variance for dry matter digestibility (\%) of test diets. 
Citation: Asad F, Qamer M, Tahir N (2014) Apparent Nutrient Digestibility Assessment and Influence of Gelatinized and Non-gelatinized Corn Starch Based Diet in Labeo rohita. J Aquac Res Development 5: 250 doi:10.4172/2155-9546.1000250

\begin{tabular}{|l|c|c|c|c|}
\hline S.O.V & d.f. & S.S. & MSS & F. Ratio \\
\hline Between diets & 5 & 41.76608 & 8.353217 & $65535^{\mathrm{NS}}$ \\
\hline Within diets & 0 & 0 & 65535 & \\
\hline Total & 5 & 41.76608 & & \\
\hline
\end{tabular}

NS=Non-significant $(P>0.05) ;{ }^{*}=$ Significant $(P<0.05) ;{ }^{* *}=$ Highly significant $(P<0.01)$ The apparent nutrient digestibility coefficient (ADC) of crude fat was maximum for the $\mathrm{T}_{6}$ : NG, $40 \% \mathrm{CP}(79.60 \%)$ and this was followed by the $\mathrm{T}_{5}: \mathrm{G}, 40 \% \mathrm{CP}$ $(74.70 \%), T_{3}: G, 35 \% \mathrm{CP}(72.50 \%), \mathrm{T}_{4}: \mathrm{NG}, 35 \% \mathrm{CP}, \mathrm{T}_{2}: \mathrm{NG}, 30 \% \mathrm{CP}(71.80 \%$ and $68.90 \%)$ and $\mathrm{T}_{1}: \mathrm{G}, 30 \% \mathrm{CP}(65.50 \%)$.

Table 4: Analysis of variance for ash digestibility (\%) of test diets.

\begin{tabular}{|l|c|c|c|c|}
\hline S.O.V & d.f. & S.S. & MSS & F. Ratio \\
\hline Between diets & 5 & 117.0333 & 23.40667 & $65535^{\mathrm{NS}}$ \\
\hline Within diets & 0 & 0 & 65535 & \\
\hline Total & 5 & 117.0333 & & \\
\hline
\end{tabular}

NS=Non-significant $(P>0.05) ;{ }^{*}=$ Significant $(P<0.05) ;{ }^{* *}=$ Highly significant $(P<0.01)$

Table 5: Analysis of variance for crude fat digestibility (\%) of test diets.

\begin{tabular}{|l|c|c|c|c|}
\hline S.O.V & d.f. & S.S. & MSS & F. Ratio \\
\hline Between diets & 5 & 1770.968 & 354.1937 & $65535^{\mathrm{NS}}$ \\
\hline Within diets & 0 & 0 & 65535 & \\
\hline Total & 5 & 1770.968 & & \\
\hline
\end{tabular}

NS=Non-significant $(P>0.05) ;{ }^{*}=$ Significant $(P<0.05) ; * *=$ Highly significant $(P<0.01)$ The apparent nutrient digestibility coefficient (ADC) of gross energy was maximum for the $\mathrm{T}_{6}$ : NG, $40 \% \mathrm{CP}(32.10 \%)$ and this was followed by the $\mathrm{T}_{5}: \mathrm{G}, 40 \% \mathrm{CP}$ (27.70\%), T : G, 35\% CP (26.85\%), T: NG, 35\% CP, T: G, 30\% CP $(26.00 \%$ and $22.72 \%)$ and $\mathrm{T}_{2}: \mathrm{NG}, 30 \% \mathrm{CP}(22.59 \%)$.

Table 6: Analysis of variance for crude protein digestibility (\%) of test diets.

\begin{tabular}{|l|c|c|c|c|}
\hline S.O.V & d.f. & S.S. & MSS & F. Ratio \\
\hline Between diets & 5 & 62.56873 & 12.51375 & $65535^{\text {NS }}$ \\
\hline Within diets & 0 & 0 & 65535 & \\
\hline Total & 5 & 62.56873 & & \\
\hline
\end{tabular}

NS=Non-significant $(P>0.05) ;{ }^{*}=$ Significant $(P<0.05) ;{ }^{* *}=$ Highly significant $(P<0.01)$

The statistical analysis of the above mentioned results (Tables 3-7) showed nonsignificant variations among all experimental diets while Figure 1 and 6 indicated the highest digestibility of dry matter in $T_{1}$ and $T_{6}(7 \%)$ within diets while figure 4 depicted the maximum ash consumption in $\mathrm{T}_{4}(12 \%)$ with different test diets. Crude protein was highest (38\%) in $\mathrm{T}_{2}$ as shown in Figure 2 whereas crude fat and gross energy were maximum digestible by $\mathrm{T}_{3}(52 \%$ and $19 \%)$ as shown in Figure 3 [16].

Table 7: Analysis of variance for gross energy digestibility (\%) of test diets.

$$
\mathrm{T} 3(\mathrm{G}, 35 \% \mathrm{CP})
$$

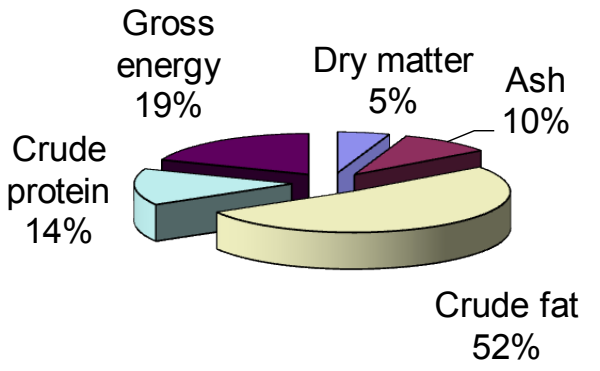

Figure 3: Apparent nutrient digestibility coefficient (\%) for $T_{3}(G, 35 \% C P)$.

This also showed that protein levels has no effect on carbohydrate digestibility as reported by Misra [10] 28\% and 35\% CP levels showed non-significant variations among G/NG corn. Our results indicates that maximum ash consumption occurs in non-gelatinized corn at $35 \%$ protein level in fish same as reported by Kumar [11], Singh [12], Mohanta [13] that 35\% protein level observed to be the optimum for contents of ash retention. Sethuramalingam and Haniffa [14] reported high lipid digestibility at $35 \%$ protein level while Yengkokpam [2] reported fat digestibility affected by increasing level of gelatinization in corn. On contrary, present study indicates the lipid digestibility better at $40 \%$ protein level in non-gelatinized corn test diet comparing all other in L. rohita. These results also indicated that fat digestibility affected by different protein levels as reported by Misra[10], both G/ NG corn showed non-significant variations with reference to different protein levels. Yengkokpam [2] reported the maximum protein digestibility at gelatinized $40 \%$ protein level in L. rohita while NG, $30 \%$ CP diet produced better protein digestibility, nutrient utilization and energy compared to other [14], as proper balance between dietary protein and energy is important for optimum growth. Less energy of rohu fingerlings fed low protein (30\%) reported [14]. Total energy and carbohydrate digestibility were found $80 \%$ in fish fed NG, 35\% CP [11]. On contrary, results from present study indicate the maximum total digestible energy in test diet with non-gelatinized $40 \%$ protein level,

\section{$\mathrm{T} 4(\mathrm{NG}, 35 \% \mathrm{CP})$}

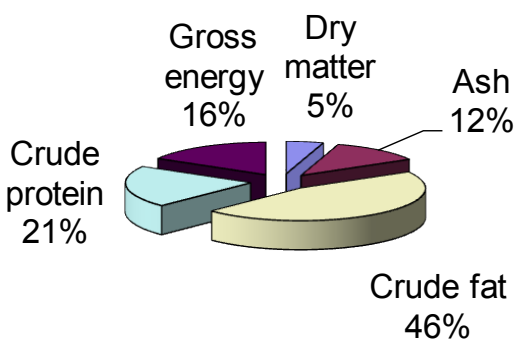

Figure 4: Apparent nutrient digestibility coefficient (\%) for $T_{4}$ (NG, 35\% CP).

\section{$\mathrm{T} 5(\mathrm{G}, 40 \% \mathrm{CP})$}

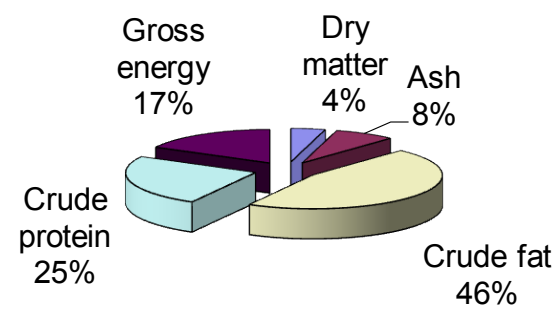

Figure 5: Apparent nutrient digestibility coefficient (\%) for $T_{5}(\mathrm{G}, 40 \% \mathrm{CP})$.

T6(NG,40\%CP)

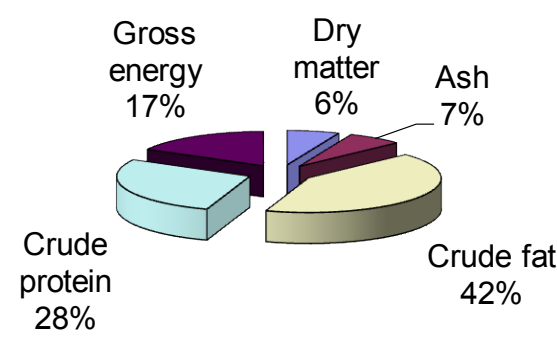

Figure 6: Apparent nutrient digestibility coefficient (\%) for $\mathrm{T}_{6}(\mathrm{NG}, 40 \% \mathrm{CP}$ ). 


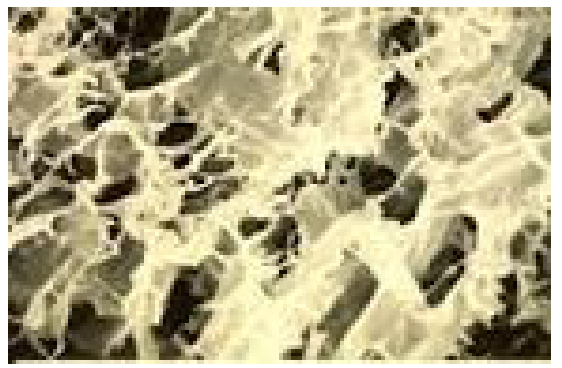

Figure 7: Microscopic view of a new gelatinized starch.

which means that gelatinization, affected the rate of digestibility in L. rohita in every aspect i.e. dry matter, ash, lipid, protein and gross energy while $40 \%$ protein level proves suitable in dry matter, lipid and total energy digestibility while $30 \%$ for protein digestibility in L. rohita which is in agreement with Kumar [11]; Mohapatra [15] (Figures 3-7).

\section{Conclusion}

It may, therefore, be concluded that non-gelatinized corn at $40 \%$ protein level proved as a promising fish feed ingredient being more efficiently utilized and gave better growth, digestibility and tissue deposition results in Labeo rohita. The palatability of non-gelatinized corn and its excellent nutritional value including high level of protein and relatively high nutritional digestibility, proved to be a high quality ingredient for this fish [16]. The results of present study could be useful as starting point for formulating cost effective, nutritionally balanced fish diets by sparing protein with carbohydrate sources. Since gelatinization is a diffusion controlled reaction, both the swelling and solubility outcome as important parameters among the factors affecting the extent of gelatinization. In gelatinization of normal corn starch, both processes seemed to be effective, while in the case of Hylon VII the solubilization of starch controlled the process. Another important point to be noted is that free amylose rather than the total in starch affected the gelatinization.

\section{References}

1. Food and Agriculture Organization of United Nation (2009) National Aquaculture sector overview, Pakistan.

2. Yengkokpam S, Sahu NP, Pal AK, Mukherjee SC, Debnath D (2007) Gelatinized carbohydrates in the diet of Catlacatla fingerlings: Effect of levels and sources on nutrition utilization, body composition and tissue enzyme activities. Journal of Animal Science 20: 89-99.

3. Kumar V, Sahu NP, Pal AK, Kumar S (2006) Immunomodulation of Labeo rohita juveniles due to dietary gelatinized and non gelatinized starch. Fish Shellfish Immunol 23: 341-353.

4. Jane J, Chen YY, Lee LF, McPherson AE, Wong KS, et al., (1999) Effects of amylopectin branch chain length and amylose content on the gelatinization and pasting properties of starch. Cereal Chem 76: 629-637.

5. Tester RF, Morrison WR (1990) Swelling and gelatinization of cereal starches. I Effects of amylopectin, amylose and lipids. Cereal Chem 67: 551-557.

6. http://archive.org/stream/gov.law.aoac.methods.1.1990/aoac. methods.1.1990_djvu.txt

7. Bligh EG, Dyer WJ (1959) A rapid method of total lipid extraction and purification. Can J Biochem Physiol 37: 911-917.

8. Divakaran S, Leonard GO, lan PF (2002) Note on the methods for determination of chromic oxide in shrimp feeds. Journal of Agricultural and Food Chemistry 50: 464-467.

9. Hassan MR (2001) Nutrition and feeding for sustainable aquaculture development in the $3^{\text {rd }}$ millennium. Bangladesh Agricultural University, Bangladesh.

10. Misra S, Sahu NP, Pal AK, Xavier B, Kumar S, et al., (2006) Pre- and postchallenge immuno-haematological changes in Labeo rohita juveniles fed gelatinized or non-gelatinized carbohydrate with n-3 PUFA. Fish Shellfish Immunol 21: 346-356.

11. Kumar V, Sahu NP, Pal AK, Kumar S, Sharma P, et al., (2008)Non-gelatinized starch influences the deposition of $n-3$ fatty acids in the muscle of a tropical freshwater fish, Labeo rohita. Journal of Animal Physiology and Animal Nutrition 93: 659-668.

12. Singh RK, Balange AK, Ghughuskar MM (2006) Protein sparing effect of carbohydrates in Cirrhinusmrigala Hamilton, 1822 fry. Aquaculture 258: 680684

13. Mohanta KN, Mohanty SN, Jena JK (2007) Protein-sparing effect of carbohydrate in silver barb, Puntiusgonionotusfry. Aquaculture Nutrition 13: 311-317.

14. Sethuramalingam TA, Haniffa MA (2001) Utilization of carbohydrate rich ingredients in the feed of Indian major carp, Labeo rohita. Indian Journal of Fisheries 48: 303-312.

15. Mohapatra M, Sahu NP, Chaudhari A (2002) Utilization of gelatinized carbohydrate in diets of Labeo rohita fry. Aquaculture nutrition 9: 189-196.

16. Leach HW, McCowen LD, Schoch T (1959) Structure of the starch granule. I. Swelling and solubility patterns of various starches. Cereal Chem 36: 534-544. 